\title{
Lead Inhibits Secretion of Osteonectin/SPARC without Significantly Altering Collagen or Hsp47 Production in Osteoblast-like ROS $17 / 2.8$ Cells
}

\author{
John J. Sauk,* Timothy Smith, ${ }^{*}$ Ellen K. Silbergeld, $\nmid$ Bruce A. Fowler, $\nmid$ And Martha J. Somerman $\ddagger$ \\ *Department of Pathology, University of Maryland Dental School, Baltimore, Maryland 21201; †Toxicology Program, Department of Pathology, \\ University of Maryland School of Medicine, Baltimore, Maryland; and $\ddagger$ Department of Periodontics, Prevention and Geriatrics, \\ University of Michigan School of Dentistry, Ann Arbor, Michigan
}

Received February 28, 1992; accepted June 8, 1992

Lead Inhibits Secretion of Osteonectin/SPARC without Significantly Altering Collagen or Hsp47 Production in Osteoblastlike ROS 17/2.8 Cells. SAUK, J. J., SMITH, T., SilbERgeld, E. K., Fowler, B. A., AND Somerman, M. J. (1992). Toxicol. Appl. Pharmacol. 116, 240-247.

In an effort to better understand the consequences of lead $\left(\mathrm{Pb}^{2+}\right)$ on skeletal growth, the effects of $\mathrm{Pb}^{2+}$ were investigated using ROS $17 / 2.8$ bone-like cells in vitro. These studies revealed that $\mathrm{Pb}^{2+}\left(4.5 \times 10^{-6} \mathrm{M}-4.5 \times 10^{-7} \mathrm{M}\right)$ has little or no effect on cell shape except when added immediately following seeding of the cells. However, proliferation of ROS cells was inhibited, in the absence of serum, at concentrations of $4.5 \times 10^{-6} \mathrm{M} \mathrm{Pb}^{2+}$. Protein production was generally increased, however, the major structural protein of bone, type I collagen, production was only slightly altered. Following treatment of ROS cells with $\mathrm{Pb}^{2+}$, intracellular levels of the calcium-binding protein osteonectin/ SPARC were increased. Osteonectin/SPARC secretion into the media was delayed or inhibited. Coincident with retention of osteonectin/SPARC there was a decrease in the levels of osteonectin/SPARC mRNA as determined by Northern analysis. These studies suggest that processes associated with osteonectin/ SPARC translation and secretion are sensitive to $\mathrm{Pb}^{2+}$. (C) 1992 Academic Press, Inc.

Lead $\left(\mathrm{Pb}^{2+}\right)$ is a toxic substance that is known to impair skeletal growth even at levels of exposure for the general population $(0.75 \mu \mathrm{M})$ (Mooty et al., 1975; Angle and Huseman, 1989; Shukla et al., 1989; Schwartz et al., 1986; Frisanch and Ryan, 1991). There are several indications that $\mathrm{Pb}^{2+}$ by its interactions with calcium $\left(\mathrm{Ca}^{2+}\right)$ may perturb many normal calcium regulatory processes, e.g., its action as a second messenger, interactions with calcium binding and other extracellular proteins associated with mineralized tissues and subcellular functions at the level of the mitochondria, synaptosomes, and membrane vesicles. Furthermore, lead is known to affect protein synthesis (Shelton et al., 1986), particularly by increasing proteins that constitute nuclear and cytoplasmic inclusion bodies (Moore et al., 1973;
Richter et al., 1968; Choie et al., 1975; McLachlin et al., 1980; Shelton and Egle, 1982), two glucose regulated proteins (Shelton et al., 1986) and by deminishing the levels of the bone related protein, osteocalcin (Angle et al., 1990; Long et al., 1989, 1990).

In addition to osteocalcin, there is increasing evidence that other noncollagenous proteins associated with mineralized tissues play a critical role in the regulation of osteogenesis. This has led to increased research emphasis on purifying, characterizing, and identifying the role of these proteins in the mineralization process (for reviews see Butler 1985; Fisher et al., 1987; Glimcher and Lian, 1989). Many of these proteins are acidic and are known to bind both $\mathrm{Ca}^{2+}$ and hydroxylapatite, suggesting a role for them in the initial phases of mineralization. Also, some bone related proteins such as osteonectin/SPARC (secreted protein, acid and rich in cysteine) mRNA have been localized to areas of active tissue morphogenesis and are expressed in cells and tissues that exhibit high rates of turnover, secretion, and remodeling (Funk and Sage, 1991). In the studies reported here we seek to determine if $\mathrm{Pb}^{2+}$ alters the characteristics of ROS 17/2.8 bone-like cells in vitro. Also, this study determines whether $\mathrm{Pb}^{2+}$ affects the production of two recognized bone matrix components, collagen and osteonectin/SPARC. Furthermore, we examine the effect of $\mathrm{Pb}^{2+}$ on $\mathrm{Hsp} 47$, a resident endoplasmic reticulum protein of cells producing type I collagen (Nakai et al., 1990; Sauk et al., 1990b).

\section{MATERIALS AND METHODS}

Cell culture. Cloned bone cell lines (ROS 17/2.8) derived from ACI9935 rat osteosarcoma were used. These cells have the advantage that their osteoblastic-like phenotypic characteristics are maintained in vitro (Majeska et al., 1980). Cells were cultured in Dulbecco's modified Eagle's medium (DMEM) supplemented with $1.16 \mathrm{~g} / \mathrm{l}$ glutamine, 100 units $/ \mathrm{ml}$ penicillin, $100 \mu \mathrm{g} / \mathrm{ml}$ streptomycin, and $10 \%$ fetal bovine serum (FBS). Lead glutamate was prepared by preparing a stock solution containing $4.5 \times 10^{-2} \mathrm{M}$ lead nitrate (Sigma) and $5.0 \times 10^{-2} \mathrm{M}$ glutamic acid in water.

Proliferation rate. To evaluate the effects of lead on cell proliferation, ROS $17 / 2.8$ cells were seeded into tissue culture wells ( $35 \mathrm{~mm}$ Falcon), 
$\approx 8.0 \times 10^{3}$ cells/well, with DMEM supplemented with $10 \%$ FBS and antibiotic and incubated overnight at $37^{\circ} \mathrm{C}$. On the following day, the medium was removed from each well and medium added as follows: (a) DMEM + $10 \%$ FBS + glutamic acid; (b) DMEM + 2\% FBS + glutamic acid; (c) DMEM $+0 \%$ FBS + glutamic acid; (d) DMEM + 2\% FBS + lead glutamate; and (e) DMEM + 0\% FBS + lead glutamate. The effects of lead glutamate on cell proliferation were evaluated at three different concentrations, $4.5 \times 10^{-5}$ $\mathrm{M}, 4.5 \times 10^{-6} \mathrm{M}$ and $4.5 \times 10^{-7} \mathrm{M}$. Cell proliferation, on Day 2, Day 4, and Day 6 after seeding, was determined by trypsinizing cells and counting electronically using a Coulter counter.

Determination of total protein and collagen production. The methods for labeling cells have been reported previously (Somerman et al., 1987). Briefly, $1.0 \times 10^{4}$ cells per test well (Falcon, $35-\mathrm{mm}$ wells) were seeded in wells in DMEM with 10\% FBS and antibiotics. After cells attached and spread, medium was removed and cells were incubated for $48 \mathrm{hr}$ in serumfree DMEM with $20 \mu \mathrm{Ci} / \mathrm{ml} \mathrm{L-5}-\left[{ }^{3} \mathrm{H}\right]$ proline and (a) glutamic acid (control) or (b) $4.5 \times 10^{-6} \mathrm{M}$ lead glutamate. Media and cell samples were then dialyzed extensively against cold buffer ( $\mathrm{pH} 7.4,0.05 \mathrm{M}$ Tris- $\mathrm{HCl}, 0.2 \mathrm{M} \mathrm{NaCl}, 0.005$ $\mathrm{M} \mathrm{CaCl}_{2}$ ). Following dialysis, aliquots of these samples were counted in a liquid scintillation spectrometer (Packard Tri Carb 460C) in Aquasol-2 (New England Nuclear (NEN) Boston, MA). These counts represented total nondialyzable radioactive material and were taken as a measure of total protein production.

To estimatc collagen production, an aliquot of the above dialyzed material was reacted for $6 \mathrm{hr}$ at $37^{\circ} \mathrm{C}$ with chromatographically purified bacterial collagenase (Form III, Advance Biofactures) according to methods of Peterkofsky and Diegelmann (1971). Undigested proteins were precipitated with $5 \%$ trichloroacetic acid/0.5\% tannic acid and samples were centrifuged. An aliquot of the supernatant was counted in Aquasol-2 (NEN) with a liquid scintillation counter. To provide a background value for the collagenase assays, additional aliquots of dialyzate were treated as above except that bacterial collagenase was excluded from these samples. The resulting backgrounds were subtracted from the collagenase-treated series to yield a value which represented collagen production expressed as collagenase digestible protein.

To determine the effects of lead on protein synthesis, cells were incubated with ${ }^{35} \mathrm{~S}$-methionine and $4.5 \times 10^{-6} \mathrm{M}$ lead glutamate for $20 \mathrm{~min}$ and then cell and media were harvested separately, as described above. Nonradioactive wells were run in parallel with these experiments to obtain total number of cells/well at time of harvest. The cells were harvested with $0.08 \%$ trypsin/ $0.04 \%$ EDTA and total cell number per well was determined electronically by Coulter counter. All assays were run in triplicate and data expressed as CPM $\times 10^{-3} / 10^{6}$ cells.

Gel electrophoresis. For polyacrylamide gel electrophoresis (PAGE), cells were seeded and exposed to $4.5 \times 10^{-6} \mathrm{M}$ lead glutamate and radioactively labeled exactly as described above. Media and cell samples were dialyzed extensively against distilled water and lyophilized. Comparable cell and media samples, of control and lead-treated cells, were dissolved in gel buffer. Thus, any variation in protein profiles among samples is based on altered protein production/well during the labeling period. Following reduction with mercaptoethanol, the samples were analyzed by gel electrophoresis on SDS 4$20 \%$ polyacrylamide gradient slab gels according to the method of Laemmli (1970). The gels were fixed, dricd, and autoradiographed using the method of Bonner and Laskey (1974).

Immunablotting. For Western blots, $3 \times 10^{6}$ cells were plated and SDSPAGE was performed as described above and proteins were immediately electrotransferred to nitrocellulose paper (Towbin et al., 1979). The paper was blocked with $3 \%$ bovine serum albumin (BSA) in $10 \mathrm{~mm}$ Tris- $\mathrm{HCl}, \mathrm{pH}$ $7.4 .0 .9 \mathrm{M} \mathrm{NaCl}$ (TBS) for $\mathrm{I}$ hr and then in TBS/BSA with $2 \%$ normal goat serum (NGS-GIBCO). Antiserum, rabbit-anti-bovine osteonectin (gift of L. Fisher NIDR/NIH), or preimmune serum were diluted 1:2000 in the same solution and incubated with gentle shaking overnight. The nitrocellulose paper was then rinsed three times for $5 \mathrm{~min}$ in TBS/Tween. The secondary antibody, affinity-purified goat-anti-rabbit $\operatorname{IgG}(\mathrm{Fc})$ horseradish peroxidase
(Kirkegaard \& Perry Labs, Inc., Gaithersburg, MD) was diluted to $0.9 \mu \mathrm{g} /$ $\mathrm{ml}$ and incubated with the paper for $2 \mathrm{hr}$. Washing between steps was performed three times for $30 \mathrm{~min}$ with $50 \mathrm{mM}$ Tris- $\mathrm{HCl}, 0.9 \mathrm{M} \mathrm{NaCl}, 0.05 \%$ Tween, pH 7.4. Staining was accomplished with 4-chloro-naphthol. For Hsp47, polyclonal rabbit antibodies were prepared against a 22-mer peptide corresponding to the $\mathrm{N}$-terminal sequence of chick Hsp47 (Hirayoshi et al., 1991) that was conjugated to Keyhole limpit hemocyanin (Sauk et al., 1990b).

Immunoprecipitation. Cell layers having equal cell numbers were homogenized in $2 \times$ immunoprecipitation buffer $(0.2 \mathrm{M}$ Tris- $\mathrm{HCl}, 0.3 \mathrm{M} \mathrm{NaCl}$., $2 \%$ Triton X-100, 2\% deoxycholate, $0.2 \%$ SDS, pH 7.2) and diluted with cold distilled water to $1 X$, while the culture media was diluted $3: 1$ with $4 \times$ immunoprecipitation buffer. The homogenates and media were then centrifuged for $5 \mathrm{~min}$ at $10,000 \mathrm{~g}$ in an Eppendorf centrifuge and a $50-\mu \mathrm{l}$ sample of the radiolabeled supernatant was added to a mixture of GammaBind GAgarose (Genex, Gaithersburg, MD) and antibody in PBS-azide. The samples were then incubated at $4^{\circ} \mathrm{C}$ with constant shaking and then centrifuged at $10,000 \mathrm{~g}$ for $10 \mathrm{~min}$. The resulting immunoprecipitate pellets were then washed twice with PBS-azide. The final pellets were suspended in $2 \times$ gel electrophoresis sample huffer, heated for $10 \mathrm{~min}$ at $90^{\circ} \mathrm{C}$, and then centrifuged to remove GammaBind G-agarose. Samples of the supernatants were counted in a scintillation counter and another sample analyzed by PAGE and autoradiography as described above. Autoradiograms were densitometrically scanned and data were reported as ratio of treated to control samples.

Northern analysis. Total RNA from $4 \times 10^{6}$ ROS $17 / 2.8$ cells was solubilized in $500 \mu \mathrm{l} 4 \mathrm{M}$ guanidinium thiocyanate containing $25 \mathrm{~mm}$ sodium acetate ( $\mathrm{pH} 5.0$ ) and $100 \mathrm{mM} \beta$-mercaptoethanol, transferred to an Eppendorf tube containing 20- $\mu \mathrm{g}$ of calf liver tRNA, and precipitated by addition of $450 \mu \mathrm{l}$ of $100 \%$ ethanol. RNA pellets were reprecipitated in the presence of $80 \%$ ethanol containing $100 \mathrm{mM}$ sodium acetate $(\mathrm{pH} 5.0)$ at $-20^{\circ} \mathrm{C}$, and equal amounts of RNA were immediately loaded onto Northerns. RNA was transferred to nitrocellulose and hound to the paper by baking at $80^{\circ} \mathrm{C}$ for $2 \mathrm{hr}$ in vacuo. A 1.5-kb EcoRI restriction fragment of a bovine osteonectin cDNA (Sauk et al., 1991) was radiolabeled by nick translation (Amersham Kit) using $\alpha-\left[\mathrm{P}^{32}\right] \mathrm{dCTP}$ and hybridized to filter bound RNA. Hybridization was carried out at $37^{\circ} \mathrm{C}$ in a mixture of $40 \%$ formamide, $0.1 \mathrm{~g} / \mathrm{ml}$ dextran sulfate, $5 \times \operatorname{SSC}$ ( $74 \mathrm{~mm}$ sodium citrate, $750 \mathrm{~mm}$ sodium chloride), $10 \mathrm{~mm}$

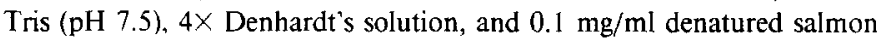
sperm DNA. The filters were washed in a solution of $2 \times$ SSC, $0.1 \%$ SDS three times for $15 \mathrm{~min}$ at $25^{\circ} \mathrm{C}$ and autofluorographed. Values of the osteonectin/SPARC mRNA (arbitrary densitometric units) were normalized to the amount of ribosomal RNA.

Attachment assay. The attachment assay utilized is similar to that of Klebe (1974). Uncoated polystyrene bacteriological 24-well plates (bacteriological petri dishes, 25820 special Corning) containing the specific factor being evaluated. i.e., fibronectin $(10 \mu \mathrm{g} / \mathrm{ml}$, positive control) or lead glutamate at a concentration of $4.5 \times 10^{-6} \mathrm{M}$ and $4.5 \times 10^{-7} \mathrm{M}$, were preincubated for $1 \mathrm{hr}$ at $37^{\circ} \mathrm{C}$ in $0.4 \mathrm{ml}$ DMEM containing $1 \mathrm{mg} / \mathrm{ml}$ bovine serum albumin (BSA, Fraction V Miles Laboratories, Inc.). Control wells had DMEM plus BSA. Following the conditioning period ROS $17 / 2.8$ cells, at a concentration of $3 \times 10^{4}$ cells in $0.1 \mathrm{ml}$ of DMEM/BSA were added to the wells. Incubation was continued for an additional $90 \mathrm{~min}$ and wells were rinsed with Hanks' balanced salt solution to remove unattached cells. Photographs, as needed, were taken at this time to document cell spreading. Cells remaining were removed enzymatically with $0.08 \%$ trypsin $/ 0.04 \%$ EDTA and counted electronically using a Coulter counter.

Cell spreading. Cell spreading was determined by photographing six representative microscopic fields at $\times 10$. The photographic images were then captured using an ELMO visual presenter (EV-368) and the shape of the resulting cells was determined following image analyses using NIH lmage (1.40) software

Statistical analyses. All experiments consisted of at least triplicate determinations. The statistical significance of differences in effects of $\mathrm{Pb}^{2+}$ on cells was determined by analysis of variance and Duncan's multiple range test. 


\section{RESULTS}

Initially, lead acetate and lead glutamate were both evaluated for use in these in vitro assays. Lead acetate added to DMEM, at comparable doses to lead glutamate $\left(10^{-5} \mathrm{M}\right)$, resulted in the formation of an immediate visible precipitate. No visible precipitate was noted in lead glutamate solutions, including the $4.5 \times 10^{-2} \mathrm{M}$ stock solution. Thus, lead glutamate was selected for use in determining the effects of $\mathrm{Pb}^{2+}$ on bone cells, in vitro.

For proliferation studies cells were exposed to three concentrations of $\mathrm{Pb}^{2+}, 4.5 \times 10^{-5} \mathrm{M}, 4.5 \times 10^{-6} \mathrm{M}$, and $4.5 \times$ $10^{-7} \mathrm{M}$ in DMEM/2\% FBS or DMEM/0\% FBS. After 1 day exposure of cells to $4.5 \times 10^{-5} \mathrm{M} \mathrm{Pb}^{2+}$ in DMEM/0\% FBS a visible precipitate was noted. By Day 4 a similar precipitate was noted in cells exposed to $10^{-5} \mathrm{M} \mathrm{Pb}^{2+}$ in DMEM/2\% FBS and a decrease in cell proliferation was noted compared to controls (Fig. 1). Concentrations of $\mathrm{Pb}^{2+}$ less than $4.5 \times$ $10^{-5} \mathrm{M}$ had no effect on cell proliferation in the presence of serum. However, in the absence of serum, $4.5 \times 10^{-7} \mathrm{M} \mathrm{Pb}^{2+}$ increased cell proliferation at Day 4 whilc, $4.5 \times 10^{-6} \mathrm{M}$ $\mathrm{Pb}^{2+}$ inhibited proliferation, but not until Day 6 .

The in vitro attachment assay revealed that $\mathrm{Pb}^{2+}(4.5 \times$ $\left.10^{-6} \mathrm{M}-4.5 \times 10^{-8} \mathrm{M}\right)$ did not affect cell attachment. Furthermore, fibronectin attached cells were not displaced by the addition of $\mathrm{Pb}^{2+}$ to the media (Table 1). However, if $\mathrm{Pb}^{2+}$ $\left(4.5 \times 10^{-6} \mathrm{M}\right)$ was incorporated into the medium of cells within the first $3 \mathrm{hr}, 92 \pm 3 \%$ the cells that attached did not go on to spread (Fig. 2A). This nonspread condition persisted for up to 4 days, after which the experiment was terminated.
TABLE 1

Effect of Lead on Attachment of ROS 17/2.8 Cells

\begin{tabular}{|c|c|c|}
\hline Treatment & $\begin{array}{l}\text { Number of cells } \\
\text { attached/well }\end{array}$ & $\begin{array}{c}\% \\
\text { Attached } \\
\text { of applied }\end{array}$ \\
\hline Control & $960 \pm 236$ & $3.2 \pm 0.8$ \\
\hline FN & $15407 \pm 1345^{a}$ & $51.4 \pm 4.5$ \\
\hline Na glutamate $\left(0.5 \times 10^{-5} \mathrm{M}\right)$ & $1009 \pm 130$ & $3.4 \pm 0.4$ \\
\hline $\mathrm{Pb}$ glutamate $\left(4.5 \times 10^{-5} \mathrm{M}\right)$ & $1073 \pm 301$ & $3.6 \pm 1.0$ \\
\hline $\mathrm{Pb}$ glutamate $\left(4.5 \times 10^{-6} \mathrm{M}\right)$ & $1062 \pm 415$ & $3.5 \perp 1.4$ \\
\hline $\mathrm{Pb}$ glutamate $\left(4.5 \times 10^{-7} \mathrm{M}\right)$ & $1083 \pm 108$ & $3.6 \pm 0.4$ \\
\hline Na glutamate $\left(5.0 \times 10^{-5} \mathrm{M}\right)+\mathrm{FN}$ & $16622 \pm 2043^{a}$ & $55.4 \pm 6.8$ \\
\hline $\mathrm{Pb}$ glutamate $\left(4.5 \times 10^{-5} \mathrm{M}\right)+\mathrm{FN}$ & $14529 \pm 1366^{a}$ & $48.4 \pm 4.5$ \\
\hline $\mathrm{Pb}$ glutamate $\left(4.5 \times 10^{-6} \mathrm{M}\right)+\mathrm{FN}$ & $14220 \pm 1038^{a}$ & $47.4 \pm 3.5$ \\
\hline $\mathrm{Pb}$ glutamate $\left(4.5 \times 10^{-7} \mathrm{M}\right)+\Gamma \mathrm{N}$ & $15189 \pm 2503^{a}$ & $50.6 \pm 8.3$ \\
\hline
\end{tabular}

${ }^{a} p<0.05$ when compared with control wells.

Note. FN, fibronectin. All agents were evaluated in triplicate and data expressed as number of cells attached \pm SD $\left(3.0 \times 10^{4}\right.$ cells per well were applied). There were day to day variations in the number of cells applied. For clarity and consistency results are expressed as the number of cells attached per well $\pm \mathrm{SD}$.

If the cells were allowed to attach and spread overnight, $\mathrm{Pb}^{2+}$ added to the medium did not affect spreading, consequently $85 \pm 9 \%$ of $\mathrm{Pb}^{2+}$ treated and $87 \pm 6 \%$ of control cells were noted to spread (Fig. 2).

Based on proliferation and attachment results, $\mathrm{Pb}^{2+}$ at 4.5 $\times 10^{-6} \mathrm{M}$ was added $24 \mathrm{hr}$ after plating and used in assays designed to determine the effect of $\mathrm{Pb}^{2+}$ on biosynthetic ac-
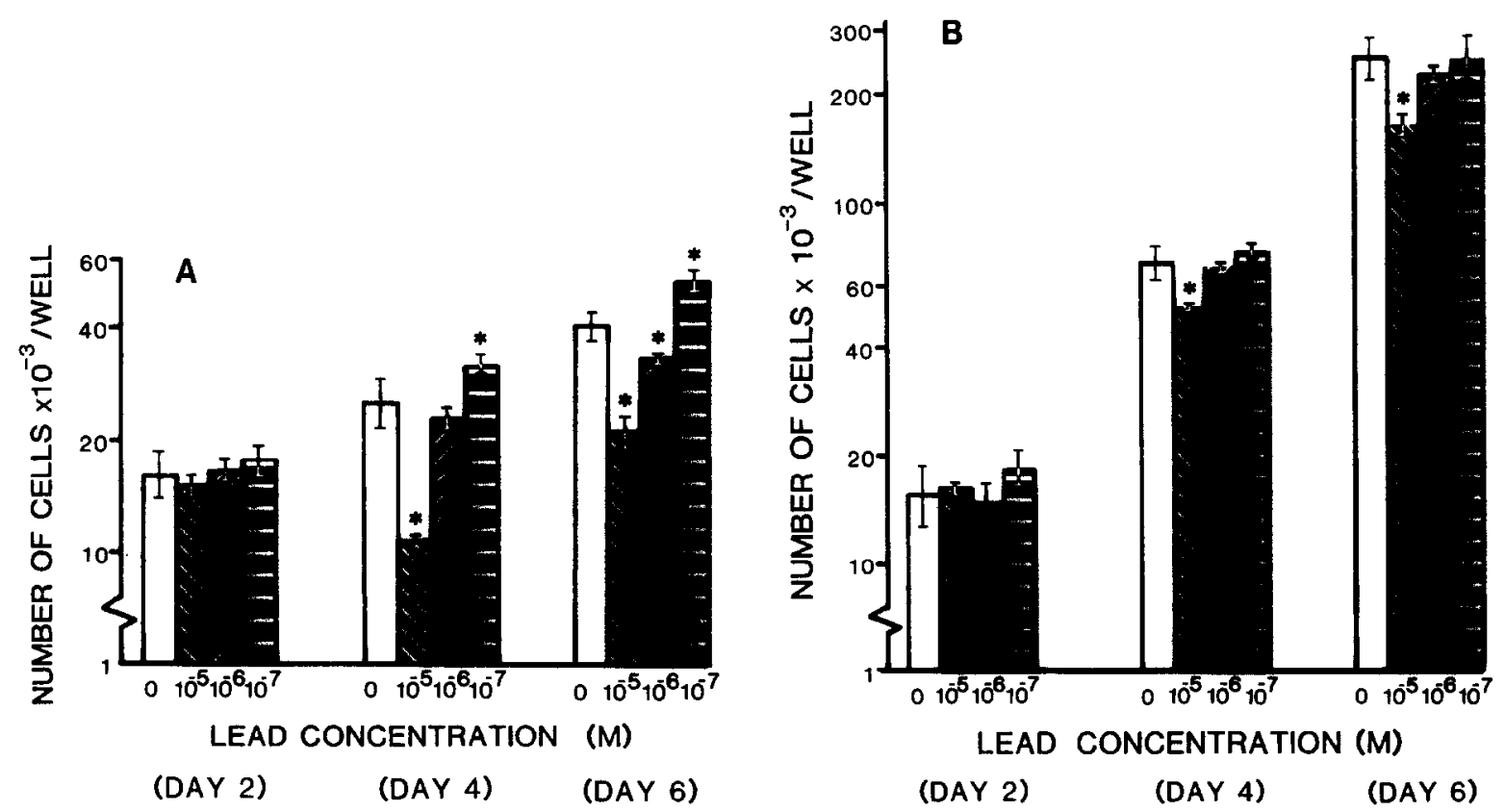

FIG. 1. The effect of lead glutamate $\left(4.5 \times 10^{-5}-4.5 \times 10^{-7} \mathrm{M}\right)$ in the absence (A) and presence (B) of $2 \%$ fetal bovine serum on the proliferation of ROS 17/2.8 cells. Data represent the mean of three determinations \pm the standard deviation (T). *Indicates significantly $(p=0.05)$ different from control by ANOVA. 


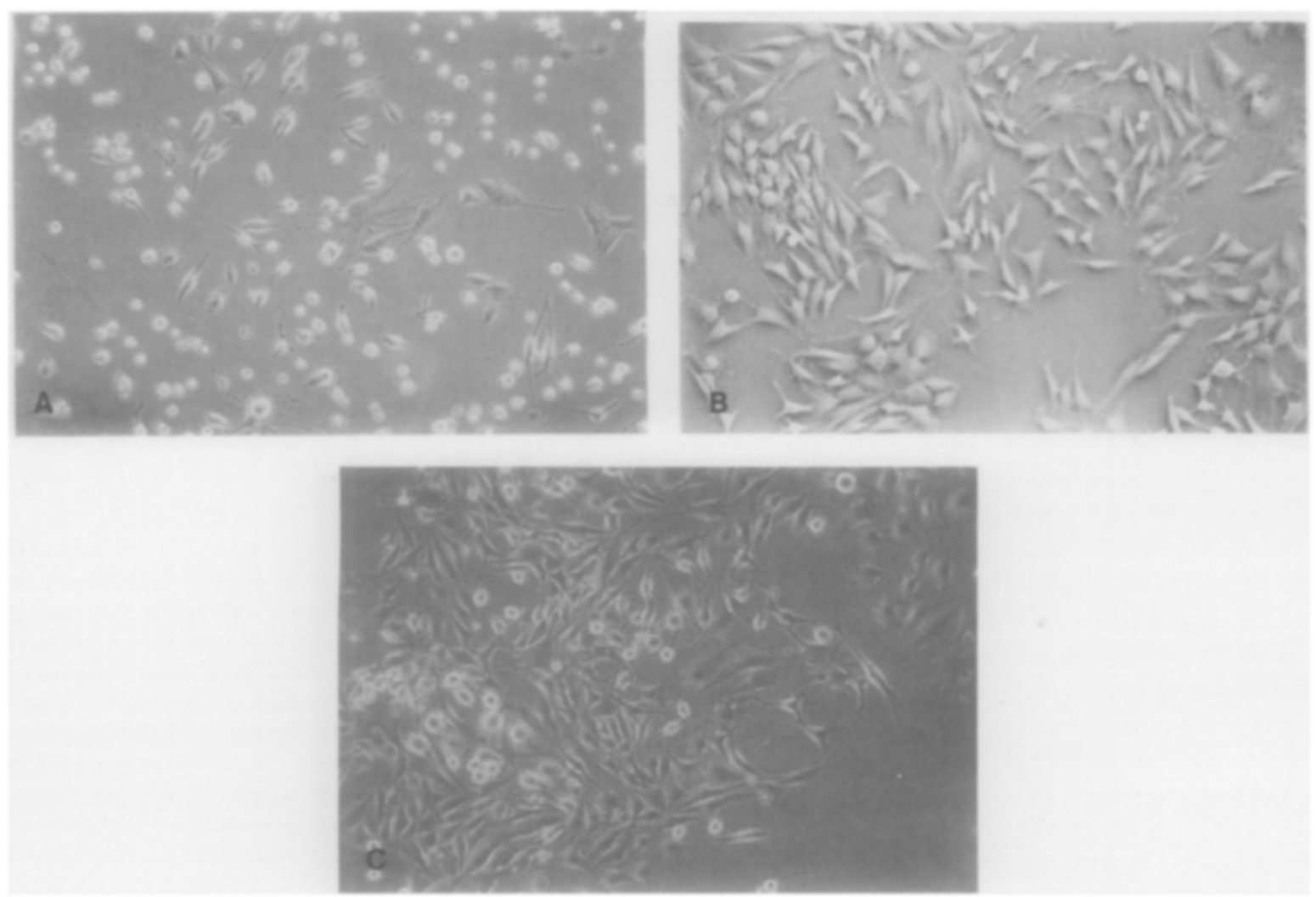

FIG. 2. (A) Attached and rounded (unspread) ROS $17 / 2.8$ cells treated with $4.5 \times 10^{-6} \mathrm{M} \mathrm{Pb}^{2+} 3 \mathrm{hr}$ after plating. Cells were then maintained for an additional $21 \mathrm{hr}$ in a humidified atmosphere as described under Materials and Methods. (B) Attached and spread ROS 17/2.8 cells that were treated with $4.5 \times 10^{-6} \mathrm{M} \mathrm{Pb}^{2+} 12 \mathrm{hr}$ after plating. Cells were then maintained for an additional $12 \mathrm{hr}$ in a humidified atmosphere as described under Materials and Methods. (C) Control cells grown for $24 \mathrm{hr}$ as described under Materials and Methods. Results represent the mean of four separate experiments.

tivity of ROS $17 / 2.8$ cells, in vitro. Both media and cells exposed to $\mathrm{Pb}^{2+}$ for $48 \mathrm{hr}$ exhibited a significant increase in total protein production/cell, approximately 30 and $40 \%$, respectively, when compared to control. In contrast, no sig-

TABLE 2

Effect of Lead Glutamate on Protein and Collagen Production by ROS 17/2.8 Cells

\begin{tabular}{lcc}
\hline & $\begin{array}{c}\text { Total protein production } \\
\left(\mathrm{CPM} \times 10^{-3}\right)\end{array}$ & $\begin{array}{r}\text { Collagen production } \\
\left(\mathrm{CPM} \times 10^{-3}\right)\end{array}$ \\
\hline $\begin{array}{l}\text { Cell } \\
\text { Control }\end{array}$ & $708 \pm 86$ & $67 \pm 15$ \\
$\quad$ Lead & $990 \pm 78^{*}$ & $96 \pm 33$ \\
Media & & \\
$\quad$ Control & $540 \pm 42$ & $158 \pm 17$ \\
Lead & $698 \pm 61^{*}$ & $169 \pm 25$ \\
\hline
\end{tabular}

Note. Cells labeled with $\left[{ }^{3} \mathrm{H}\right]$ proline were exposed to lead glutamate for $48 \mathrm{hr}$ at a concentration of $4.5 \times 10^{-6} \mathrm{M}$. Results are expressed as means \pm standard deviation. These results were representative of three separate experiments.

${ }^{*} p<0.05$ signficantly from control wells. nificant increase in collagen production was observed (Table 2). To determine whether $\mathrm{Pb}^{2+}$ had a short-term effect on cellular proteins (i.e., protein synthesis) ROS $17 / 2.8$ cells were exposed to $4.5 \times 10^{-6} \mathrm{M} \mathrm{Pb}^{2+}$ for $20 \mathrm{~min}$ and radio-
TABLE 3

Effect of Lead Glutamate on Protein Synthesis by ROS $17 / 2.8$ Cells

\begin{tabular}{cc}
\hline & $\begin{array}{c}\text { Total protein synthesis } \\
\left(\mathrm{CPM} \times 10^{-3}\right)\end{array}$ \\
\hline Cell & \\
Control & $357 \pm 51$ \\
Lead & $431 \pm 54^{*}$ \\
Media & \\
Control & $35 \pm 9$ \\
Lead & $33 \pm 5$ \\
\hline
\end{tabular}

Note. ${ }^{35} \mathrm{~S}$-methionine and $4.5 \times 10^{-6} \mathrm{M}$ lead glutamate were added to wells for $20 \mathrm{~min}$ and then media and cells were harvested separately. Results are expressed as means \pm standard deviation. These results were representative of three separate experiments.

${ }^{*} p<0.05$ significantly different from control wells. 
actively labeled during this time period. As seen in Table 3, $\mathrm{Pb}^{2+}$ exposed cells exhibited an increase in protein synthesis, but not in secreted (media) proteins.

To further investigate these changes, we analyzed the effect of varying $\mathrm{Pb}^{2+}$ concentrations on cellular levels of Hsp47, a collagen-binding glycoprotein associated with collagen assembly and sorting, and on the acidic bone-related protein, osteonectin/SPARC. Hsp47 levels, as with collagen production, were not altered by $\mathrm{Pb}^{2+}$ treatment (Fig. 3). Conversely, cellular levels of osteonectin werc noted to be enhanced following $\mathrm{Pb}^{2+}$ exposure (Fig. 4). Examination of the media following $\mathrm{Pb}^{2+}\left(4.5 \times 10^{-6} \mathrm{M}\right)$ treatment revealed that osteonectin/SPARC levels were not detectable, by optical density comparison, to that of control cells (Fig. 5). Exposure of $\operatorname{ROS} 17 / 2.8$ cells to $4.5 \times 10^{-5}-4.5 \times 10^{-7} \mathrm{M} \mathrm{Pb}^{2+}$ for a shorter duration $(20 \mathrm{~min})$ followed by immunoprecipitation of cell proteins with anti-osteonectin antibodies revealed a dose-dependent decrease in synthesis of osteonectin/SPARC (Fig. 6). Northern analysis of osteonectin mRNA (2.2 kb) showed no differences between $\mathrm{Pb}^{2+}$ treated $\left(4.5 \times 10^{-6} \mathrm{M}\right)$ for $1 \mathrm{hr}$ and control cells. However, if cells were exposed to $\mathrm{Pb}^{2+}$ for $24 \mathrm{hr}$, osteonectin/SPARC mRNA levels were reduced by threefold compared to control cells (Fig. 7).

\section{DISCUSSION}

The data reported here demonstrate that $\mathrm{Pb}^{2+}$ decreases the proliferation of bone cells in vitro and enhances cellular protein production. The ability of $\mathrm{Pb}^{2+}$ to decrease $\mathrm{ROS} \mathrm{17/}$ 2.8 proliferation is in agreement with similar studies by Long et al. (1990). However, at comparable doses $\left(4.5 \times 10^{-6} \mathrm{M}\right)$ we observe decreased cell growth by Day 6 , whereas Long et al. did not observe decreased cell growth until Day 9. The reason for these differences may include the experimental design. Although both studies used ROS 17/2.8 cells, we used 0 and $2 \%$ serum whereas they used $5 \%$ serum. Higher serum levels may lower the concentration of unbound $\mathrm{Pb}^{2+}$ available to cells. We also used lead glutamate, while they used lead acetate which is particularly prone to form precipitates (McLachlin et al., 1980).

The importance of cell adhesion in the regulation of many physiological and pathological events including development, platelet aggregation, wound healing, and malignant invasion prompted us to further investigate the effects of $\mathrm{Pb}^{2+}$ on bone cell attachment. The adhesion of cells to a substratum, in vitro is frequently regulated by calcium dependent, receptorligand interactions. Thus a reasonable hypothesis for the observed decreased cell attachment would be that $\mathrm{Pb}^{2+}$, by competing with $\mathrm{Ca}^{2+}$ at the cellular membrane, may interfere with receptor-ligand interactions and subsequently cell attachment and spreading. Previous studies reported that marrow cells exposed to $\mathrm{Pb}^{2+}\left(1-10 \mu \mathrm{M} \mathrm{Pb}^{2+}\right)$ for 10 days exhibited decreased adherence to tissue culture dishes (Kowolenko et al., 1989). The ability for ROS $17 / 2.8$ cells to attach, but

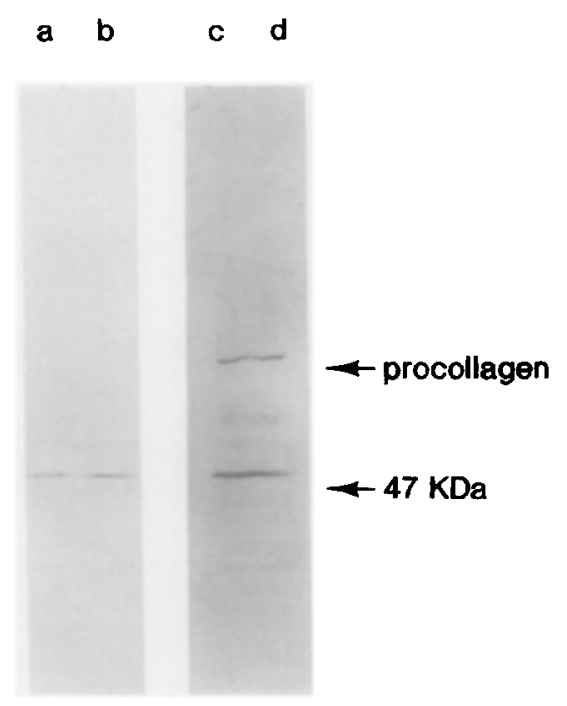

FIG. 3. The effect of $4 \mathrm{hr}$ of $4.5 \times 10^{-6} \mathrm{M} \mathrm{Pb}^{2+}$ on Hsp47 in ROS 17/ 2.8 cells. Lanes a and $b$ represent Western blots utilizing anti-Hsp47 antibodies. Control lane a and $\mathrm{Pb}^{2+}$ treated lane b. ROS 17/2.8 cells. Hsp47 was enriched by binding to gelatin-Sepharose (Sauk et al., 1990) prior to PAGE. Lanes c (Control) and $\mathrm{d}\left(\mathrm{Pb}^{2+}\right.$ treated) represent autoradiographs of ${ }^{35} \mathrm{~S}$ methionine-labeled $(4 \mathrm{hr})$. ROS $17 / 2.8$ proteins immunoprecipitated with anti-Hsp47 antibodies. In addition to $\mathrm{Hsp} 47, \alpha \mathrm{I}(\mathrm{I})$ procollagen chains are coimmunoprecipitated with anti-Hsp47 antibodies (Nakai et al., 1990). The optical density of precipitates in Western blots and bands in immunoprecipitate autoradiograms were determined by gel scanner as a component of NIH Imagc (1.4) software. These analyses revealed relative optical density differences of $<0.05$ between control and $\mathrm{Pb}^{2+}$ treated cells.

not spread following the early on addition of $\mathrm{Pb}^{2+}$ indicates that these events, in bone cells, are temporally mediated. Also, once spreading has developed $\mathrm{Pb}^{2+}$ cannot reverse this process. However, in our studies, no effect on cell attachment was noted in distinction to effects observed with marrow cells (Kowolenko et al., 1989). Furthermore, cells already attached through a calcium dependent integrin receptor-fibronectin interaction were not detached by doses of $\mathrm{Pb}^{2+}$ that were sufficient to alter protein production and cell proliferation. The separate modulation of cell spreading and proliferation has been noted previously. Funk and Sage (1991) showed that SPARC inhibited cell proliferation and caused cell rounding of endothelial cells. Furthermore, inhibition of cell doubling was attributed to a 20 -residue synthetic peptide (2.1) derived from a non- $\mathrm{Ca}^{2+}$-binding, disulfide-rich region of SPARC, while cell rounding was promoted by sequences 5-23 in the calcium-binding region of the molecule. In the present study, there was no secretion of osteonectin/SPARC to cause cell rounding in the first few hours. However, $\mathrm{Pb}^{2+}$ might alter a membrane receptor, ion pump, or disturb a second messenger system (Borke et al., 1988; Busselberg et al., 1991) controlling cell shape.

Lead's ability to modulate both the synthesis and production of proteins by ROS 17/2.8 cells appears to be directed at least in part to acidic calcium binding proteins. Thus, 


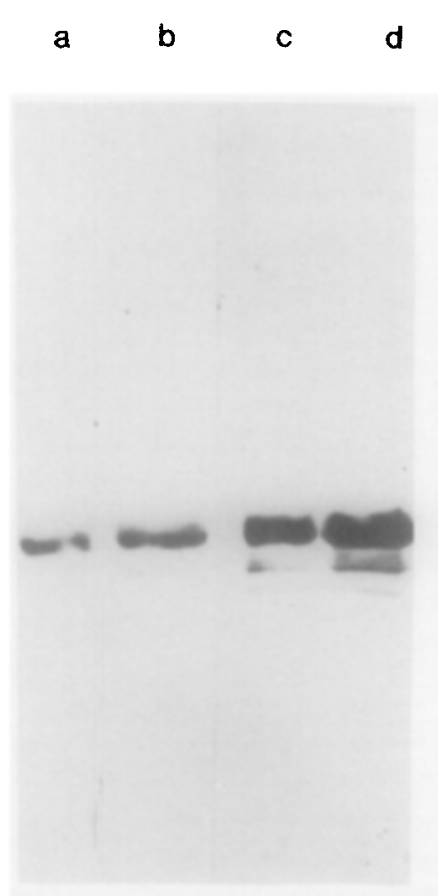

FIG. 4. Western blot of cellular osteonectin/SPARC ( $43 \mathrm{kDa})$ using anti-osteonectin antibodies, in ROS $17 / 2.8$ cells following exposure to various concentrations of lead glutamate for $4 \mathrm{hr}$. (a) control; (b) $4.5 \times 10^{-7} \mathrm{M} \mathrm{Pb}^{2+}$; (c) $4.5 \times 10^{-6} \mathrm{M} \mathrm{Pb}^{2+}$; (d) $4.5 \times 10^{-5} \mathrm{M} \mathrm{Pb}^{2+}$. Lower molecular weight bands observed in lanes $\mathrm{c}$ and $\mathrm{d}$ were considered to represent minor alterations in protcin processing, i.c., glycosylation or phosphorylation. Results represent the mean of three separate experiments.

collagen and Hsp47 levels are unchanged whereas cellular levels of osteonectin/SPARC are enhanced and secretion similar to osteocalcin (Angle et al., 1990; Long et al., 1989, 1990 ) is inhibited. However, the increased cellular levels of osteonectin/SPARC ensue while synthesis, depicted by shortterm ${ }^{35} \mathrm{~S}$-methionine labeling, is diminished. Shelton et al. (1986) similarly demonstrated that $\mathrm{Pb}^{2+}$ enhances the level of an acidic (pI 6.3) inclusion body protein in kidney cells, and Fowler et al. (1985) showed increases in the synthesis of acidic gene products in rats given a single low dose of $\mathrm{Pb}^{2+}$ which induced intranuclear inclusions in renal proximal tubule cells. However, unlike the $\mathrm{Pb}^{2+}$-induced nuclear proteins, osteonectin/SPARC is secreted, though delayed, in the presence of $\mathrm{Pb}^{2+}$ and is found in the medium. Lead inhibits this release possibly by affecting the conformation of osteonectin/SPARC as well as other acidic calcium-binding proteins. As a result, these proteins are retained in the ER. The inhibition or delayed secretion of structurally altered proteins is common and delayed synthesis, even in the presence of equivalent levels of mRNA, may ensue as a consequence of retention or delayed secretion of protein from the ER (Byers, 1990).

The diminished levels of osteonectin/SPARC mRNA in cells treated with $\mathrm{Pb}^{2+}$ for $24 \mathrm{hr}$ signifies that pretranslational events controlling these acidic cellular proteins may also be
FIG. 5. Immunoprecipitation of ${ }^{35} S$-methionine-labeled $(4 \mathrm{hr})$ osteonectin/SPARC ( $43 \mathrm{kDa}$ ) from the media of ROS $17 / 2.8$ cells following $4 \mathrm{hr}$ treatment with $4.5 \times 10^{-6} \mathrm{M} \mathrm{Pb}^{2+}$ and continuously labeled with ${ }^{35} S$-methionine. (a) control; (b) $4.5 \times 10^{-7} \mathrm{M} \mathrm{Pb}^{2+}$; (c) $4.5 \times 10^{-6} \mathrm{M} \mathrm{Pb}^{2+}$. Results represent the mean of three separate experiments.

affected by $\mathrm{Pb}^{2+}$. The accumulation, over time, of $\mathrm{Pb}^{2+}$ in the nucleus (Shelton, 1986) may place $\mathrm{Pb}^{2+}$ in proximity to transcriptional events. Proteins such as $\mathrm{p} 21 / 6.2$, associated with nuclear matrices, have been implied in affecting DNA replication, RNA transcription, mitogenesis, and cell proliferation (Mistry et al., 1985, 1986; Klann and Shelton, 1989; Fowler and Duval, 1991). Candidates for posttranscription and/or pretranslational affects of $\mathrm{Pb}^{2+}$ include the $\mathrm{p} 220$ component of an eukaryotic initiation factor $4 \mathrm{~F}$ and regucalcin-like proteins. The p220 component functions in the first step of the binding of capped mRNAs to the small ribosomal subunit and has been shown to be a substrate for
a
b
c
d

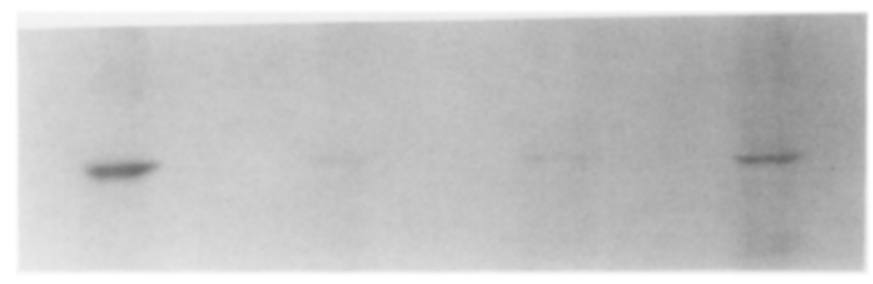

FIG. 6. Immunoprecipitation of cellular osteonectin/SPARC following 20 min treatment with various concentrations of lead glutamate. (a) control; (b) $4.5 \times 10^{-5} \mathrm{M} \mathrm{Pb}^{2+}$; (c) $4.5 \times 10^{-6} \mathrm{M} \mathrm{Pb}^{2+}$; (d) $4.5 \times 10^{-7} \mathrm{M} \mathrm{Pb}^{2+}$. Results were reproduced in three separate experiments. 
a

b

C

d

FIG. 7. Northern analysis of ROS 17/2.8 cells. Panel represents an autoradiogram of ${ }^{32} \mathrm{P}$-nick-labeled bovine osteonectin cDNA hybridized to ROS 17/2.8 RNA migrating to $2.2 \mathrm{~kb}$. (a) control cells, (b) $4.5 \times 10^{-6} \mathrm{M}$ $\mathrm{Pb}^{2+}$ for $1 \mathrm{hr}$, (c) control cells ( $24 \mathrm{hr}$ ), (d) $4.5 \times 10^{-6} \mathrm{M} \mathrm{Pb}^{2+}$ (24 hr). Although equal amounts of RNA were loaded in each paring, autoradiograms of lanes $c$ and $d$ were exposed for a longer period in order to visualize lane $d$. Results were reproduced in two separate experiments.

multiple calcium-dependent enzymes (Wyckoff et al., 1990). Regucalcin, a calcium-binding protein derived from cytosol, regulates $\mathrm{Ca}^{+2}$ mediated cell function by inhibiting aminoacyl-tRNA synthetase activity (Yamaguchi and Mori, 1990).

Thus, these studies demonstrate further that $\mathrm{Pb}^{2+}$ has a pleiotropic effect on bone cells. ER processes, possibly associated with calcium-dependent protein folding, appear to be sensitive to $\mathrm{Pb}^{+2}$, resulting in retention or delayed protein secretion. In contrast, receptor-mediated attachment to substratum is undisturbed by $\mathrm{Pb}^{2+}$. Future studies directed at establishing the mechanism for the alteration of specific bone proteins in cells exposed to $\mathrm{Pb}^{2+}$ are warranted and will help to clarify the effect of $\mathrm{Pb}^{2+}$ on bone growth and possibly provide a molecular marker for $\mathrm{Pb}^{2+}$ exposure in the environment.

\section{ACKNOWLEDGMENTS}

This research was supported by Agency for Toxic Substances and Disease Registry through Centers for Disease Control Project H75/ATH390067 awarded by the Maryland Department of the Environment in cooperation with University of Maryland at Baltimore, DE-08648 and AR-41572 NIH. Thanks are extended to Ms. Jo-Ann Walker for preparation of the manuscript.

\section{REFERENCES}

Angle, C. R., and Huseman, C. A. (1989). Childhood blood lead: Growth and neuroendocrine toxicity. Vet. Hum. Toxicol. 31, 341.

Angle, C. R., Thomas, D. J., and Swanson, S. A. (1990). Lead inhibits the basal and stimulated responses of a rat osteoblast-like cell line ROS 17/ 2.8 to $1 \alpha .25$-dihydroxyvitamin D3 and IGF-I. Toxicol. Appl. Pharmacol. 103, 281-287.

Bonner, W. M., and Laskey, R. A. (1974). A film detection method for tritium-labeled proteins and nucleic acids in polyacrylamide gels. Eur. $J$. Biochem. 46, 83-88.

Borke, J. L., Eriksen, E. F., Minami, J., Keeting, P., Mann, K. G., Penniston, J. T., Riggs, B. L., and Kumar, R. (1988). Epitopes of the human erythrocyte $\mathrm{Ca}^{2+}-\mathrm{Mg}^{2+}$ ATPase pump in human osteoblast-like cell plasma membranes. J. Clin. Endocrinol. Metab. 67, 1299-1304.

Busselberg, D., Evans, M., Rahmann, H., and Carpenter, D. O. (1991). Lead and zinc block a voltage-activated calcium channel of Aplysia neurons. J. Neurophysiol. 65, 786-795.
Butler, W. T. (Ed.) (1985). The Chemistry and Biology of Mineralized Tissues. Fibsco Media, Inc., Birmingham, Alahama.

Byers, P. H. (1990). Mutations in collagen genes: Biochemical and phenotypic consequences. In Extracellular Matrix Genes (L. J. Sandell and C. D. Boyd, Eds.), pp. 251-265, Academic Press, New York.

Choie, D. D., Richter, G. W., and Young, L. B. (1975). Biogenesis of intranuclear lead-protein inclusions in mouse kidney. Beitr. Path. Bd. 155, 197-203.

Fisher, L. W., Hawkins, G. R., Tuross, N., and Termine, J. D. (1987). Purification and partial characterization of small proteoglycans I and II, bone sialoprotein I and II and osteonectin from the mineral compartment of developing human bone. J. Biol. Chem. 262, 9702-9708.

Fowler, B. A., and Duval, G. E. (1991). Effects of lead on the kidney: Roles of high affinity lead-binding proteins. Environ. Health Perspect. 91, 7780 .

Fowler, B. A., Mistry, P., and Victery, W. W. (1985). Ultrastructural morphometric studies of lead inclusion body formation in kidney proximal tubule cells: Relationship to altered renal protein synthetic patterns. Toxicologist 5, 53 .

Frisanch, R. A., and Ryan, A. S. (1991). Decreased stature associated with moderate blood lead concentrations in Mexican-American children. Am. J. Clin. Nutr. 54, 516-519.

Funk, S. E., and Sage, H. (1991). The $\mathrm{Ca}^{2+}$-binding glycoprotein SPARC modulates cell cycle progression in bovine aortic endothelial cells. Proc. Nall. Acad. Sci. 88, 2648-2652.

Glimcher, M. J., and Lian, J. B. (Eds.) (1989). Chemistry and Biology of Mineralized Tissues, Proc. of 3rd International Conf. Gordon Breach Sci. Pub., Boston.

Hirayoshi, K., Kudo, H.. Takechi, H., Nakai, A., Iwamatsu, A., Yamada, K., and Nagata, K. (1991). Hsp47: A tissue specific, transformation-sensitive, collagen-binding heat shock protein of chick embryo fibroblasts. Mol. Cell Biol. 11, 4036-4044.

Klann, E., and Shelton, K. (1989). The effect of lead on the metabolism of a nuclear matrix protein which becomes prominent in lead induced intranuclear inclusion bodies. J. Biol. Chem. 264, 16969-16972.

Klebe, R. (1974). Isolation of collagen-dependent cell attachment factor. Nature 250, 248-251.

Kowolenko, M., Tracy, L., and Lawrence, D. A. (1989). Lead-induced a1terations in in vitro bone marrow cell responses to colony stimulating factor-1, J. Leuk. Biol. 45, 198-206.

Laemmli, U. K. (1970). Cleavage of structural proteins during the assembly of the head bacteriophage T4. Nature 227, 680-685.

Long, G. J., Rosen, J. F., and Pounds, J. G. (1989). The effect of lead on osteocalcin in rat osteosarcoma 17/2.8 cells. Toxicologist $9,20$.

Long, G. J., Rosen, J. F., and Pounds, J. G. (1990). Lead impairs the production of osteocalcin by rat osteosarcoma (ROS 18/2.8) cells. Toxicol. Appl. Pharmacol. 106, 270-277.

Majeska, R. J., Rodan, S. B., and Rodan. G. A. (1980). Parathyroid hormoneresponsive clonal cell lines from rat osteosarcoma. Endocrinology 107, 1494-1503.

McLachlin, J. R., Goyer. R. A., and Cherian, M. G. (1980). Formation of lead-induced inclusion bodies in primary rat kidney epithelial cell cultures: Effect of actinomycin D and cycloheximide. Toxicol. Appl. Pharmacol. 56, 418-431.

Mistry, P., Lucier, G. W., and Fowler, B. A. (1985). High affinity leadbinding proteins from rat kidney cytosol: Mediate cell-free nuclear translocation of lead. J. Pharm. Exp. Ther. 232, 462-469.

Mistry, P., Mastri, C., and Fowler, B. A. (1986). Influence of metal ions on renal cytosolic lead binding proteins and nuclear uptake of lead in the kidney. Biochem. Pharmacol. 35, 711-713. 
Moore, J. E., and Goyer, R. A. (1973). Lead-induced inclusion bodies. Solubility, amino acid content, and relationship to residual acidic nuclear proteins. Lab. Invest. 29, 488-494.

Mooty, J., Ferrand, C. F., and Harris, P. (1975). Relationship of diet to lead poisoning in children. Pediatrics 55, 636-639.

Nakai, A., Hirayashi, K., and Nagata, K. (1990). Transformation of BALB/ 3T 3 cells by simian virus 40 causes a decrease synthesis of a collagenbinding heat-shock protein (hsp47). J. Biol. Chem. 265, 992-999.

Peterkofsky, B., and Diegelmann, R. (1971). Use of a mixture of proteinasefree collagenases for the specific assay of radioactive collagen in the presence of other proteins. Biochemistry 10, 988-994.

Richter E. S.. Kress, Y., and Cornwall, C. C. (1968). Another look at lead inclusion bodies. Am. J. Pathol. 53, 189-198.

Sauk, J. J., Van Kampen, C. L., Norris, K., Foster, R. A., and Somerman, M. J. (1990a). Expression of constitutive and inducible Hsp70 and Hsp47 are enhanced in cells persistently spread on OPN and collagen. Biochem. Biophys. Res. Commun. 172, 135-142.

Sauk, J. J., Norris, K., Foster, R. A., and Somerman, M. J. (1990b). Colligin/ Hsp47 is expressed after diverse forms of stress in fibroblasts derived from human periodontal ligaments, in vitro. Arch. Oral Biol. 35, 645-651.

Sauk, J. J., Norris, K., Kerr, J. M., Somerman, M. J., and Young, M. F. (1991). Diverse forms of stress result in changes in cellular levels of osteonectin/SPARC without altering mRNA levels in osteoligament cells. Calcif. Tissue Int 49, 58-62.
Schwartz, J., Angle, C., and Pitcher, H. (1986). Relationship between childhood blood lead levels and stature. Pediatrics 77, 281-288.

Shelton, K. R., and Egle, P. M. (1982). The proteins of lead-induced intranuclear inclusion bodies. J. Biol. Chem. 257, 11802-11807.

Shelton, K. R., Todd, J. M., and Egle, P. M. (1986). The induction of stressrelated proteins by lead. J. Biol. Chem. 261, 1935-1940.

Shukla, R., Bornschein, R. L., Dietrich, K. N., Buncher, C. R., Berger, O. G., Hammond, P. B., and Succop, P. A. (1989). Fetal and infant lead exposure: Effects on growth in stature. Pediatrics 84, 604-612.

Somerman, M. J., Prince, C. W., Sauk, J. J., Foster, R. A., and Butler, W. T. (1987). Mechanism of fibroblast attachment to bone extracellular matrix: Role of a 44 kilodalton bone phosphoprotein. J. Bone Mineral Res. 2, 259-266.

Towbin, H., Stachelin, T., and Gorgon, J. (1979). Electrophoretic transfer of proteins from polyacrylamide gels to nitrocellulose sheets: Procedure and some applications. Proc. Natl. Acad. Sci. 76, 4350-4354.

Wyckoff, E. E., Croall, D. E., and Ehrenfeld, E. (1990). The p220 component of eukaryotic factor $4 \mathrm{~F}$ is a substrate for multiple calcium-dependent enzymes. Biochemistry 29, 10055-10061.

Yamaguchi, M., and Mori, S. (1990). Effect of calcium-binding protein regucalcin on hepatic protein synthesis: Inhibition of amino-tRNA synthetase activity. Mol. Cell. Biochem. 99, 25-32. 